\title{
Interpretation of Regulation of Human Rights Law on Social Stratification
}

\author{
Qing $\mathrm{Na}^{1}$, Zhao Jianshan ${ }^{2}$ \\ ${ }^{1}$ Law School Dianchi College of Yunnan University, Kunming, 650228 \\ ${ }^{2}$ Law school Renmin University of China, Beijing, 100872
}

Keywords: social stratification; human rights law; conflict

\begin{abstract}
Social stratification has existed since ancient times and has not been completely eliminated. Since the birth of human rights law, there is a strong conflict between the value it pursues and social stratification. In order to regulate social stratification, human rights law provides many ways, including, use legislation to guarantee equal rights, combat discrimination, strengthen social mobility, prevent social stratification, strengthen social security, enable the weak to survive and ensure social peace.
\end{abstract}

\section{Human Rights Law and Social Stratification}

The human rights law, which is composed of International Human Rights Law and Domestic Human Rights Law, aims to guarantee the legal norms of human rights. It can appear in the form of law and also can appear in the form of customary law. Since the emergence of a large number of international human rights laws, such as the International Human Rights Charter, the concept of Human Rights Law has been born. The human rights legislation has been strengthened, and many laws related to human rights are born at this time. But to this day, the boundaries of Human Rights Law are still very vague, and the Human Rights Law of all countries is developed under the guidance of its own national constitution. In 2004, China formally wrote "state respect and protection of human rights" into the constitution by way of constitutional amendment.

Since the emergence of the concept of Human Rights Law, there have been various forms. Instead, these forms have led to the value pursuits of Human Rights Law, and also to its guiding ideology, which determines the contents of Human Rights Law. Whether in International Human Rights Law or in national Constitutions, legislators always write the word human rights in the preamble, making human rights the basis of other laws. By synthesizing the Constitution or constitutional documents such as the Universal Declaration of Human Rights, the Charter of the United Nations, the French Declaration of Human Rights, the German Basic Law, and so on, we can see that all laws that seek to protect human rights are those that protect freedom, equality, justice and order. So, we regard that these are the ultimate values of Human Rights Law pursuits.

Social stratification refers to the phenomenon of stratification and difference of social groups and members due to the possession of different social resources. It also refers to the institutionalized system of social differences based on laws and regulations, which reflects social inequality. The concept of the highest stratification came from geology, and was later introduced into sociology, just like geological structures, which form different levels of order, illustrating very vividly the inequalities that exist among the members of society as a result of social stratification. It includes the inequality between people and the inequality between groups.

Since the birth of the son of Zhou, there has been an "official ritual of the Zhou Dynasty". At that time, "common people are not exacted by a complete courtesy and high officials are exempt from the penalties prescribed by the law". Since then, social stratification has emerged. The history of our great Chinese nation has been five thousand years. There has always been a serious phenomenon of social stratification. Even today, we still can see or feel the strict order of social stratification, such as the speaking in ordinary meetings, or the ranking in newspaper, and so on.

Social stratification has both a positive and negative side, because the root of social stratification is unequal. The fact that the side with advantages will damage the interests of others for benefits 
causes an increase in social inequality. This is in accordance with Marx's Class Theory, but at the same time, social inequality may promote competition. Because of competition, all walks of life make the society continue to develop.

\section{Conflicts between Value Pursuits of Human Rights Law and Social Stratification}

Human Rights Law protects the rights that human beings should have. Human beings are very special creatures in this world. From the day they are born, they have human rights. As human beings, they need freedom, equality, etc. The value of human rights law is freedom, equality, justice, peace and so on. Social stratification, on the other hand, is a hierarchical system, formed by the difference of valuable goods in a society occupied and dominated by individuals and groups. Its essence is the inequality of human society. If people do not achieve equality first, then there is no Human Rights Law to talk, such as freedom, justice, peace and so on. However, because Human Rights Law is recognized by all countries, its value concept limits social stratification to a certain extent.

Freedom refers to that you can do what you want to do and say what you want to say. Legal freedom means a right or liberty guaranteed by the Constitution or other laws that protects the people from enslavement, imprisonment or control by a certain autocratic regime, or ensures that people can be liberated. Man is born free, which is the classic judgment of the great philosopher Aristotle. The conflict between freedom and social stratification has always existed. In slave and feudal society, the freedom of the lower class was greatly restricted. Sometimes there is no personal freedom to speak of. For example, in slave societies, slaves are the private property of slave owners. They can be bought, sold or even killed at will. Until in feudal society, peasants' status as a ruled class is slightly better than slaves, but still dependent on landlords, so freedom is a distant aspiration.

Legal equality refers to being equal to others in the enjoyment of rights or obligations. Equality of rights is one of the basic concepts of Human Rights Law, and equality is one of the persevering pursuits of human beings. The essence of social stratification is the inequality between people, so it is obvious that there is a great conflict between equal value and social stratification. In ancient society, there was a great difference in status between people, and one extreme example was that most of those who lost a war would become slaves, as well as their later generations. They never have their own rights since their birth.

Justice is the common pursuit of mankind, we always respect this value in life, for the value of justice, for the sake of the history of countless people with lofty ideals to throw their heads, sprinkle blood, for chapter of songs and tears written in the struggle for justice. So, it is so difficult to protect justice just because of the fragility of justice value. The realization of justice value is always threatened in one way or another, among which, social stratification greatly hinders the realization of justice. In social stratification, there are always people in an advantageous position, so their behavior of ignoring the interests of those in a weak position for their own benefit always exists, because human beings are ultimately seeking advantages and avoiding disadvantages, therefore, justice conflicts with social stratification.

\section{Ways of Human Rights Law to Regulate Social Stratification}

Human Rights Law is mostly a kind of commitment of a country to its citizens and promises to protect the rights of citizens. However, It seems that Human Rights Law cannot regulate social stratification and it is Civil Law that should regulate the relationship between people, but in fact, such a view is one-sided or even wrong. The Human Rights Law of every country is the fundamental law of each country as well as the mother law of other laws which naturally includes Civil Law. From the value pursued by Human Rights Law, Human Rights Law regulates social stratification in the following ways.

Article 4 of the Universal Declaration of Human Rights states that "no one shall be subjected to slaves or slavery. Slavery in all its forms and slave trade must be forbidden”. Article 8 of the 
International Covenant on Civil and Political Rights emphasizes the above-mentioned provisions of article 4 of the Universal Declaration of Human Rights. In addition to, Article 8 of the International Covenant on Civil and Political Rights also states that compulsory and hard labour is specifically prohibited. These are all in order to eliminate the most unjust social stratification of slavery. Privilege firstly violates the value pursuit of Human Rights Law, so social stratification based on privilege should be resisted.

"All human beings are born free and equal in dignity and rights”. It is also stipulated in the Universal Declaration of Human Rights, which aims to eliminate discrimination, so everyone is entitled to all rights and freedom without distinction in race, nationality, colour, sex, social origin, etc.

After the Universal Declaration of Human Rights, the legislation of every country imitated to write this into its Constitution or basic law, which can restricts the social stratification in legislation.

If social stratification stays still forever, then there will be a very awkward situation, that is, the society will no longer progress and no longer have vitality. The strong will be stronger and the weak will be weaker, and so will the children and grandchildren. As if everything had become a fate. Therefore, the prevention of social stratification has become a great task of Human Rights Law.

How can the Human Rights Law prevent the social stratification from solidifying? First of all, it is absolutely true that the so-called knowledge changes the fate of the citizens' right to education. The degree to which a person is educated is absolutely related to the amount of social resources he can master. Education is an important bargaining chip for a person to choose a career. Only those people who have been educated and have knowledge can they have more choices, more opportunities to participate in the country and society. To a certain extent, they will prevent the solidification of society, because, as long as we have knowledge, we can change our own level. Besides, Human Rights Law concerns and protects people's political rights. Only when citizens have equal political rights will they have the opportunity to improve their position in social class by political means. For example, by the right to vote and to be voted, citizens can have the chance to enhance their status in the social stratification. As long as political rights are equal, it is difficult for the upper class to use their advantage to exploit the lower class. Moreover, the mobility between the upper and lower class can prevent the solidification of social stratification.

As a member of society, everyone has rights to enjoy the economic, social and cultural rights which are necessary for the free development of his personal dignity and personality. To achieve this requires the joint efforts of all countries and the international community.

In social life, there are always some people at the bottom of social structure. For these people, it is not enough to protect their rights to vote and education. Some people at the bottom of social hierarchy may never be able to be at the same starting line because of family poverty or birth with disabilities and so on. Taking the right to be educated as an example, we found that education is mostly required to pay a certain amount of money. For poor people, they will lose this opportunity and never be able to use knowledge to change their destiny. In this way, only through social security can this group survive.

It is clear that the upper class has more resources, and naturally have more advantages in many social activities, especially in a country that is politically undemocratic and economically not equal. The lower levels in the social stratification do not have a lot of social resources because they do not have the opportunity to participate in national politics or are oppressed by the upper level of the social stratification. Therefore, these two sides have a deep resentment and the contradiction is becoming more and more sharp, which is likely to create a social crisis.

Therefore, by providing workers' right to strike, the right to organize trade unions, and so on in Human Rights Law to find an institutionalized export for the lower classes of society, social stability will be maintained and the effect of regulating social stratification can be achieved.

\section{Conclusion}

No matter in which country, social stratification is hard to avoid. What countries can do is to try to prevent social stratification from solidifying and to regulate social stratification by means of 
Human Rights Law and so on. Therefore, only to establish a free, equal, peaceful and just society, can we effectively regulate social stratification.

\section{References}

[1] Li Buyun. Human Rights Law [M]. Higher Education Press, 2005.

[2] Sun Liping. “Illegal Marriage” between Rights and Markets [J]. China Reform, 2006, 4. 